\title{
Influence of lifting prescribing restrictions for losartan on subsequent sartan utilisation patterns in Austria; implications for other countries
}

- Anna Bucsics, MD - Hauptverband der Österreichischen Sozialversicherungsträger, Kundmanngasse 21, A-1031 Wien, Austria

- Brian Godman, BSc, PhD*. Division of Clinical Pharmacology, Karolinska University Hospital Huddinge, SE-141 86, Stockholm, Sweden. Telephone: +468 585810 68; Fax: + 46858581070. Email: Brian.Godman@ki.se; Mario Negri Institute for Pharmacological Research, Via Giuseppe La Masa 19, 20156 Milan, Italy; Prescribing Research Group, University of Liverpool Management School, Chatham Street, Liverpool, UK L69 7ZH

- Thomas Burkhardt, MSc - Hauptverband der Österreichischen Sozialversicherungsträger, Kundmanngasse 21, A-1031 Wien, Austria. Email: Thomas.Burkhardt@hvb.sozvers.at

- Manuela Schmitzer - Hauptverband der Österreichischen Sozialversicherungsträger, Kundmanngasse 21, A-1031 Wien, Austria. Email: Manuela.Schmitzer@hvb.sozvers.at

- Rickard E Malmström MD, PhD. Department of Medicine, Division of Clinical Pharmacology, Karolinska Institutet, Karolinska University Hospital Solna, Stockholm, Sweden. Email: rickard.malmstrom@ki.se

Key words: losartan, angiotensin receptor blockers, generics, prescribing restrictions, drug utilisation studies, Austria

*Author for correspondence

(Accepted for publication Expert Review Pharmacoeconomics and Outcomes Research)

\begin{abstract}
Introduction: Prescribing restrictions for angiotensin receptor blockers (ARBs) limited their utilisation in Austria. Recently generic losartan became available with its prescribing restrictions lifted whilst still in place for patented ARBs. Objectives: Assess the impact of the lifting of the prescribing restriction on (a) utilisation of losartan in ambulatory care versus other single ARBs, (b) expenditure per DDD (defined daily dose) of losartan as well as total ARB expenditure, and (c) utilisation of ARB combinations. Lastly, suggest potential measures that could be introduced to further enhance ARB prescribing efficiency. Methodology: Quasi-experimental study of the utilisation of different ARBs alone or in fixed dose combinations (FDCs) using a segmented time series. Utilisation measured in DDDs, defined as 'the average maintenance dose of a drug when used in its major indication in adults'. Costs measured as total expenditure for different ARBs as well as their expenditure/ DDD. Results: Losartan utilisation increased significantly following the withdrawal of prescribing restrictions $(P>0.001)$. Utilisation of patented ARBs also increased, but the growth rate was appreciably reduced once restrictions were lifted for losartan $(P>0.01)$. As a result, total expenditure of single ARBs increased but at an appreciably lower rate than utilisation, helped by total expenditure/ DDD for losartan declining by $78 \%$ over the study period. There was continuing appreciable utilisation of FDCs. Conclusions: Lifting of prescribing restrictions for losartan significantly enhanced its utilisation, increasing ARB prescribing efficiency, providing direction to other European authorities. Additional reforms are needed to further switch utilisation from other ARBs to additionally improve prescribing efficiency. These are being considered as more ARBs lose their patents.
\end{abstract}

\section{Introduction}

Scrutiny over pharmaceutical expenditure has increased across Europe in recent years, with expenditure generally rising faster than other components in ambulatory care, resulting in pharmaceutical expenditure typically the largest cost component in ambulatory care [1-5]. This is set to continue unless addressed, driven by well known factors including the continued launch of new premium priced medicines, rising patient expectations and a growing elderly population [2-4, 6-9]. As a result, multiple supply- and demand-side reforms have been introduced across Europe in an effort to maintain the European ideals of equitable and comprehensive healthcare. In the case of existing drugs, these include initiatives to lower the price of molecules once multiple sources become available, compulsory price reductions, as well as reference pricing for the molecule (Anatomical Therapeutic Classification - ATC - Level 5 [101]), the class (ATC level 4) or therapeutic area (ATC Level 3) [9-19]. Demand-side measures include initiatives to enhance the prescribing or dispensing of 
generics versus originators incorporating voluntary or compulsory International Non-proprietary Nomenclature (INN) prescribing, compulsory substitution or substitution targets [1-4,7-9,11-17,19]; as well as increase the prescribing of generics versus premium priced patented products in a class or related class. Initiatives include guidelines, prescribing guidance, academic detailing, benchmarking, prescribing targets, financial incentives for all key stakeholder groups as well as prescribing restrictions [1-4,7-9,11-15,18-27].

Multiple demand-side measures are typically needed to improve prescribing efficiency as seen in Austria (particularly statins and renin-angiotensin inhibitor drugs), Sweden and the UK (England and Scotland) for the proton pump inhibitors (PPIs), statins and the renin-angiotensin inhibitor drugs ( Angiotensin converting enzyme inhibitors - ACEls - and Angiotensin Receptor Blockers - ARBs), versus Ireland and Portugal (Table 1), with their more limited demand-side measures to combat commercial pressures and encourage the prescribing of generics [1,4,7-9,11,12,14,15,20-23]. In the case of Ireland in particular, typically the utilisation of multiple sourced PPIs and statins went down, and the prescribing of patented PPIs and statins increased, once generics became available, appreciably adding to their prescribing costs versus Sweden and the UK $[8,9]$.

Table 1 - Changes in utilisation patterns for PPIs, statins and renin-angiotensin drugs (2010 DDDs) versus reimbursed expenditure 2007 vs. 2001 [7-9,12,18,20-23]

\begin{tabular}{|c|c|c|}
\hline Country & $\begin{array}{c}\text { Change in utilisation } 2007 \text { vs. } \\
2001 \text { (DDDs) }\end{array}$ & $\begin{array}{c}\text { Change in expenditure } 2007 \\
\text { vs. } 2001 \\
\end{array}$ \\
\hline Austria - PPIs & 3.6 fold increase & 2.1 fold increase* \\
\hline Austria - statins & Approximately 2.4 fold increase & $3 \%$ decrease* \\
\hline Austria - ACEls/ ARBs & $69 \%$ increase & $23 \%$ increase \\
\hline England - PPIs & 2.3 fold increase & $36 \%$ reduction \\
\hline England - statins & 5.1 fold increase & $20 \%$ increase \\
\hline Ireland $^{\star *}-$ PPIs & 2.4 fold increase & 2.6 fold increase \\
\hline Ireland $^{\star \star}-$ statins & 7.3 fold increase & 4.9 fold increase \\
\hline Portugal - PPIs & 4.3 fold increase & 2.3 fold increase \\
\hline Portugal - statins & 5.6 fold increase & 2.9 fold increase \\
\hline Portugal - ACEIs/ ARBs & $72 \%$ increase & $41 \%$ increase \\
\hline Scotland - PPIs & 2.3 fold increase & $52 \%$ reduction \\
\hline Scotland - statins & 4.9 fold increase & $16 \%$ increase \\
\hline Scotland-ACEIs/ ARBs & 2.6 fold increase & $20 \%$ increase \\
\hline Sweden - PPIs & $53 \%$ increase & $49 \%$ reduction \\
\hline Sweden - statins & 3.2 fold increase & $39 \%$ reduction \\
\hline Sweden - ACEIs/ ARBs & $92 \%$ increase & $20 \%$ increase \\
\hline
\end{tabular}

A recent study in Scotland showed that the reforms continued to enhance prescribing efficiency for the PPIs and statins, with expenditure/ 1000 inhabitants/ year in 2010 for the PPIs decreasing by 56\% compared with 2001 levels despite a 3 fold increase in utilisation (in DDDs - defined daily doses) [15]. Similarly, reimbursed expenditure for the statins only increased by $7 \%$ in 2010 compared with 2001 levels despite a 6.2 fold increase in utilisation during this period [15].

Austria is no exception. Supply side measures for existing drugs include pricing regulations for generics and originators once multiple sourced products are available as well as voluntary reference pricing in a class once standards become available as generics $[1,7,9,12,21,22]$. Under the reforms, the first generic must be priced a minimum of $48 \%$ below the originator product to be reimbursed, the second generic at least $15 \%$ lower than the first and the third generic at least $10 \%$ lower than the 
second to be reimbursed. This equates to at least $60 \%$ below the originator price once the third generic is launched. This establishes the benchmark price for all branded generics and the originator product within 3 months of the entry of the third generic (Figure 1) $[1,7,9,21,22]$. Subsequent branded generics must be priced at least 10 Euro cents per pack below the previous pack to be reimbursed. Companies do this to gain market share, with IT systems highlighting the cheapest branded generics to physicians, building on quarterly publications sent by insurance companies to ambulatory care physicians again highlighting the cheapest branded generic, as well as physicians' prescribing costs benchmarked against each other coupled with financial incentives to prescribe the cheapest branded generic $[1,21,22]$.

Figure 1 - Pricing policy for both originators and generics in Austria once multiple sourced products become available (reproduced with kind permission of Expert Review) assuming the originator was priced at $€ 20 /$ pack before losing its patent- Redrawn from reference 22]

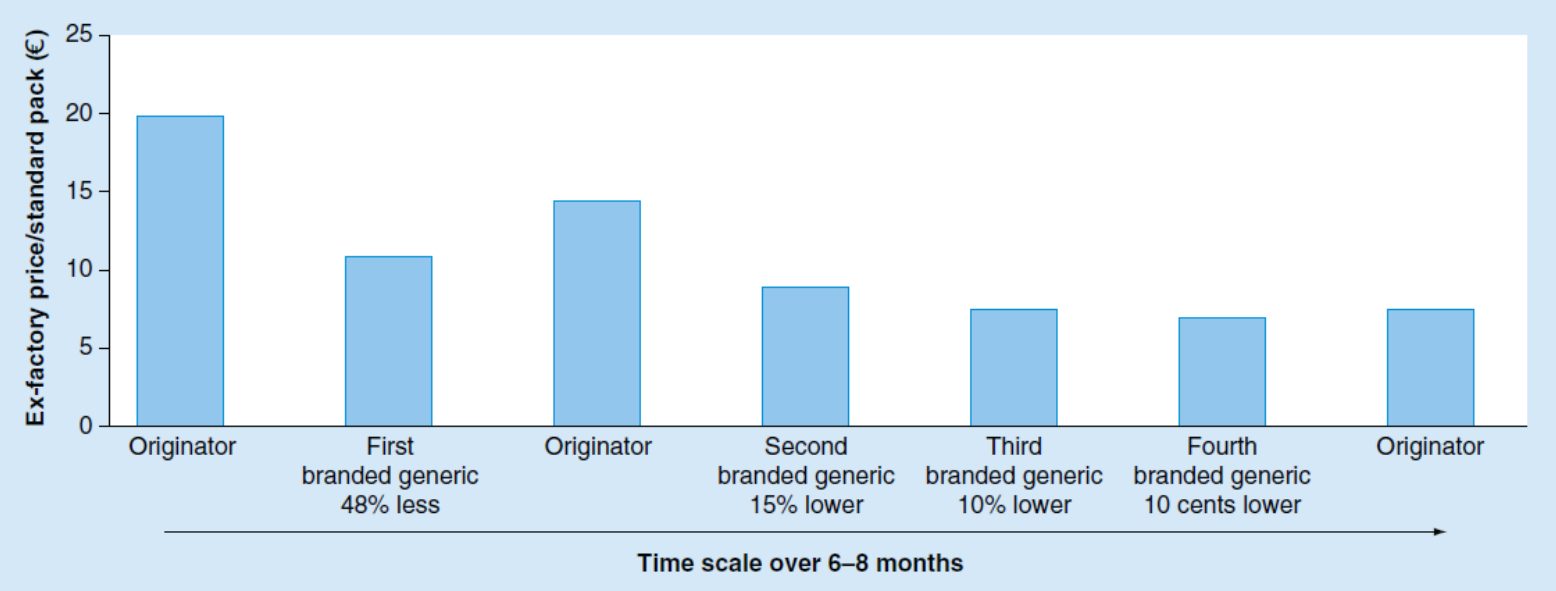

This led for instance to total expenditure/ DDD for generic ACEls up to $77 \%$ below pre-patent originator prices, generic omeprazole $77 \%$ below, and generic simvastatin $72 \%$ below pre-patent loss prices, by the end of 2007 [21,22]. The combined Social Health Insurance in Austria (Hauptverband der Österreichischen Sozialversicherungsträger - HVB) also seeks voluntary price reductions from companies with existing patented products in a class where there are seen as interchangeable and some are already available as generics [1,21]. This initiative already resulted in appreciable accumulated savings of $€ 209.2 \mathrm{mn}$ per year in 2006 [1,21]. Otherwise, prescribing restrictions are introduced for existing patented products or delisting $[1,21]$. The manufacturers of existing patented PPIs voluntarily lowered their prices to avoid restrictions once generic omeprazole became available [21]. However, the situation was different with the manufacturer of atorvastatin, leading to its prescribing being restricted to patients not achieving target lipid levels with generic statins; otherwise $100 \%$ co-payment $[8,9,20,21,23]$. This built on existing prescribing restrictions for rosuvastatin $[1,21]$. As a result, the utilisation of patented atorvastatin was considerably reduced, leading to appreciably greater efficiency savings for the statins in Austria than seen with the PPIs (Table 1).

The HVB in Austria was also one of the few authorities in Europe to restrict reimbursement of ARBs and their combinations immediately after their introduction $[12,22]$. Other countries included Croatia, Lithuania and the Republic of Srpska $[1,12,19,20]$. Western European countries including France, Germany, Italy, Norway, Spain, Sweden and the UK did not introduce prescribing restrictions, although other measures such as guidance, formularies, prescribing targets and financial incentives were introduced to help limit ARB prescribing [2-4,8,12,24-27]. Prescribing restrictions were though subsequently introduced at a later date in Sweden to further encourage the prescribing of ACEls first line [25]. Under the terms of the restriction in Austria, ARBs could only be prescribed in patients unable to tolerate ACEls due to for instance unacceptable dry coughing $[12,20,22]$. This was because there was no perceived difference in the effectiveness between ACEls and ARBs, but higher acquisition costs for the ARBs; in addition, prospective clinical studies had shown that a dry cough occurred in only approximately $10 \%$ of patients prescribed ACEls $[12,20,22,28,102]$. Alongside this, only 2 to $3 \%$ of all patients left ACEI clinical trials due to a dry cough $[21,28,29]$. Under the agreement, physicians are required to document the justification for prescribing ARBs in the patients' 
notes, and these are reviewed every 2 to 3 years. Potential sanctions for abuse include physicians paying back to the HVB an estimate of the increased drug expenditure associated with any abuse, and they may no longer being able to treat Social Health Insurance patients. The latter though is rarely instigated in practice. However, physicians do not need the permission of the Chief Medical Officer of the patient's Social Health Insurance Company before prescribing an ARB [12, 21]. This is unlike the situation with atorvastatin and rosuvastatin described above, where permission is needed before the products are reimbursed, otherwise $100 \%$ co-payment $[1,20,21,23]$.

The regulations surrounding the prescribing ARBs in Austria were complicated by the fact that the restriction was based on patient reported side effects rather than a laboratory value, as seen with the statins $[1,12,21,22]$. In addition, in practice a dry cough can occur in up to $25 \%$ of patients in selected populations, especially those prescribed higher doses for heart failure [30,31]. Having said this, the utilisation of ARBs in Austria only reached $25 \%$ of total renin-angiotensin utilisation on a DDD basis in 2007 compared with $15 \%$ in 2001 [12,20,22]. This compares with Portugal where utilisation of ARBs was $44 \%$ of total renin-angiotensin utilisation in 2007 , up from $20 \%$ in $2001[12,20]$, reducing overall prescribing efficiency versus Austria (Table 1).

The prescribing restrictions on ARBs, coupled with measures to lower the prices of generics and originators once multiple products become available (Figure 1), resulted in total expenditure on reninangiotensin drugs remaining relatively stable in Austria between 2001 and 2007 despite an appreciable increase in utilization (Table1). Total expenditure on renin-angiotensin products in Austria was $€ 16305 / 1000$ inhabitants/ year in 2007 versus $€ 13271$ in 2001 [12,20,22]. This compares with $€ 26,620 / 1000$ inhabitants/ year for reimbursed expenditure in Portugal in $2007[12,20]$.

There was also appreciable utilisation of renin-angiotensin fixed dose diuretic combinations (FDCs) in Austria between 2001 and 2007 due to limited prescribing of diuretics first line and their limited availability as single agents $[12,20,22]$. This differs from the very limited utilisation of FDCs in England and Scotland, at under $2 \%$ of total renin-angiotensin utilisation on a DDD basis in 2007, as well as Sweden where FDCs accounted for only approximately $7 \%$ of total ACEI utilisation in 2007, and slightly higher for ARB FDCs [12,22].

Prescribing restrictions for losartan were eased in Austria following the availability of generic losartan in October 2008. However, this did not apply to the other ARBs. The care of patients prescribed ARBs should not be compromised by encouraging greater prescribing of losartan versus other ARBs as a Cochrane review concluded that all ARBs are equally effective in lowering blood pressure [32, 33], although others disagree [34]. However, the National Institute for Health and Clinical Excellence (NICE) in the UK endorsed the view of the Cochrane Collaboration in their recent guidance, stating that patients with hypertension can be started on either an ACEI or a low cost ARB [103,104]. There have been no head to head randomised trials of different ARBs claiming superiority of one ARB over another for heart failure $[32,35,36]$, although higher doses of ARBs may be needed to treat heart failure as demonstrated by the HEAAL study with $150 \mathrm{mg} /$ day of losartan versus $50 \mathrm{mg}$ per day $[32,36,37]$. In addition, a recent large scale registry cohort study in Denmark showed no increased mortality for losartan versus candesartan, despite earlier suggestions, especially when higher doses of losartan (100mg per day) were used [35]. Alongside this, patients in the UK have been successfully switched between ARBs for the management of hypertension and heart failure [32,38], Greater care though may be needed when switching patients with heart failure between different ARBs $[32,104,105]$.

Consequently, the primary objective of this study is to assess the impact of easing of the prescribing restriction for losartan on its subsequent utilisation. This is because up to now prescribing restrictions have typically been applied to encourage the prescribing of higher 'valued' products first line within a class or related class, such as generic statins versus premium priced patented atorvastatin or rosuvastatin and generic ACEls versus patented ARBs [1,12,20-22]. As a result, this study adds to health policy initiatives by assessing the influence on removing a prescribing restriction for one product within a class, whilst retaining these for all other products in the class. Other objectives include: (a) whether the reduction in the price of generic losartan over time is in line with previous findings for generic ACEls, omeprazole or simvastatin, (b) assessing the influence of the availability of generic losartan coupled with the easing of its prescribing restriction on total single ARB expenditure, (c) analysing the utilisation of ARB combinations generally in Austria and suggesting possible reasons if different form previous findings, (d) suggesting additional measures that could potentially be 
introduced by the HVB in Austria if needed to further enhance ARB prescribing efficiency. Efficiency defined on this occasion as increased utilisation of multiple sourced ARBs versus patented ARBs with no perceived effectiveness or safety differences between them. As a result, provide guidance to other health authorities and health insurance agencies on potential future initiatives as they seek to further enhance the utilisation of multiple sourced ARBs in their countries to conserve resources.

\section{Methodology}

This is a quasi-experimental study [39], using a segmented time series design [40], for analyzing monthly reimbursed prescriptions for all patients in Austria covered by the social health insurance system prescribed at least one ARB alone or in combination with diuretics and other combinations (C09CA01 to 09, C09DA01 to 05, C09DX01 to 03) [101] in ambulatory care between October 2006, i.e. 2 years before generic losartan was reimbursed in Austria, to August 2011, i.e. 35 months after generic losartan was first reimbursed. Alongside this, total expenditure. The data source was the internal data warehouse of the HVB (BIG), Cube HMSTAT, based on the "maschinelle Heilmittelabrechnung", which covers approximately $98 \%$ of the Austrian population [8, 21, 22].

We are confident that we can undertake this type of analysis as the removal of prescribing restrictions for losartan was the principal intervention encouraging its prescribing versus other single ARBs. This is because the demand-side reforms described earlier typically encourage the prescribing of a branded generic versus the originator to help bring generic and overall molecule prices down $[1,21,22]$, with voluntary reference pricing or potentially prescribing restrictions applied to enhance overall prescribing efficiency for the class if needed $[1,12,21]$. This is illustrated by the findings with the PPIs, where the utilisation of esomeprazole and pantoprazole stayed relative constant before and after the availability of generic omeprazole, e.g. 11\% of total PPIs for esomeprazole in 2007 (DDD basis) vs. $10 \%$ in 2002 and $39 \%$ for pantoprazole in 2007 versus $43 \%$ in 2001 . The major change in utilisation patterns was seen with a reduction in the utilisation of rabeprazole, which was promoted based on its 'value' until generic PPIs became available [21].

Utilisation was measured in terms of Defined Daily Dose, with DDDs defined as 'the average maintenance dose of a drug when used in its major indication in adults', with this measure recognised as the international standard to assess utilisation patterns within and between countries [106]. 2011 DDDs were used in line with international guidance $[8,9,41,106]$, with the WHO methodology used to calculate the DDDs for the combination products. This was based on the principle of counting the combination as one dose $[12,22,106]$.

The regression analyses were undertaken using 'R Development Core Team' [107] where the reimbursed prescriptions were explained by a variable 'Time' with it's origin in October 2008 (generic losartan first reimbursed with its prescribing restriction removed) and a variable 'Inter' to model the change in slope following the availability of generic losartan and the removal of its prescribing restriction, onwards.

Total costs in Euros were again used for the analysis to facilitate comparisons with previous studies $[12,21,22]$. This is because it is difficult in practice to disaggregate pharmacy and wholesaler markups from total costs in Austria, compounded by 20 to $25 \%$ of the Austrian population currently exempt from basic co-payment. As a result, total costs provides a more robust measure than estimating reimbursed costs using any derived formula [21]. Total costs are the price paid to the pharmacy for the product including the ex-factory price, the wholesaler and pharmacy mark ups but excluding VAT $[21,22]$. Total expenditure per DDD was computed for each product, including originator and generics where pertinent, as well as the ARB class as a whole.

There has been no allowance for inflation as we wanted to compute the actual influence of the various policies on total expenditure as well as total expenditure/ DDD over time. In addition, the tendency of authorities across Europe is to cut prices of both patented drugs and generics when pharmaceutical expenditure is rising more rapidly than target budgets $[2,7,9,11,12-15,18]$. Alongside this, a number of European countries establish their initial prices for generics based on originator pre-patent loss prices including in Austria $[1,2,7,9,11,12,17,19,21,22]$. Consequently the use of total expenditure, as well as no allowance for inflation, is in line with previous publications $[1,2,7,9,11,12-15,17-19,21,22]$. 


\section{Results}

The lifting of the prescribing restrictions for losartan in October 2008 significantly enhanced its utilisation in ambulatory care (Table 2), with utilisation growing at an additional 18,567 DDDs/ month versus fairly constant prescribing prior to the launch of generic losartan (Figure 2).

Table 2 - Residuals and coefficients for the change in losartan utilisation before and after generic availability and the removal of prescribing restrictions

\begin{tabular}{|l|c|c|c|c|}
\hline Residuals & & & & \\
\hline \multicolumn{1}{|c|}{ Minimum } & $1 \mathrm{Q}$ & Median & $3 \mathrm{Q}$ & Maximum \\
\hline-104819 & -28514 & 5234 & 31140 & 165634 \\
\hline & & & & \\
\hline Coefficients & Estimate & Standard Error & t value & Significance \\
\hline Intercept & 523446.6 & 14507.7 & 36.081 & $>0.001$ \\
\hline Time & -957.4 & 1178.3 & -0.812 & 0.42 \\
\hline Inter & 18566.5 & 1703.9 & 10.896 & $>0.001$ \\
\hline
\end{tabular}

Residual standard error: 52320 on 56 degrees of freedom, Multiple R-squared: 0.9409 ,

Adjusted R-squared: 0.9388 , F-statistic: 445.8 on 2 and 56 DF, p-value: $<2.2 \mathrm{e}-16$

Combined with this, there was a corresponding slowing in the rate of growth in utilisation of the other ARBs when consolidated, which was also significant (Table 3). The rate of decline versus the trend seen before prescribing restrictions were lifted for losartan was 32,397DDDs/ month. Having said this, the overall utilisation of other ARBs continued to increase after prescribing restrictions were removed for losartan (Figure 2).

Table 3 - Residuals and coefficients for the change in other ARB utilisation before and after generic availability and the removal of its prescribing restrictions

\begin{tabular}{|l|c|c|c|c|}
\hline Residuals & & & & \\
\hline \multicolumn{1}{|c|}{ Minimum } & $\mathbf{1 Q}$ & Median & $\mathbf{3 Q}$ & Maximum \\
\hline-661167 & -197676 & 38607 & 144819 & 939862 \\
\hline & & & & \\
\hline Coefficients & Estimate & Standard Error & t value & Significance \\
\hline Intercept & 4869605 & 93287 & 52.2 & $>0.001$ \\
\hline Time & 7.035 & 7577 & 7.035 & $>0.001$ \\
\hline Inter & -32397 & 10956 & -2.957 & $>0.01$ \\
\hline
\end{tabular}

Residual standard error: 336400 on 56 degrees of freedom, Multiple R-squared: 0.7475 ,

Adjusted R-squared: 0.7385 , F-statistic: 82.88 on 2 and 56 DF, p-value: $<2.2 \mathrm{e}-16$ 


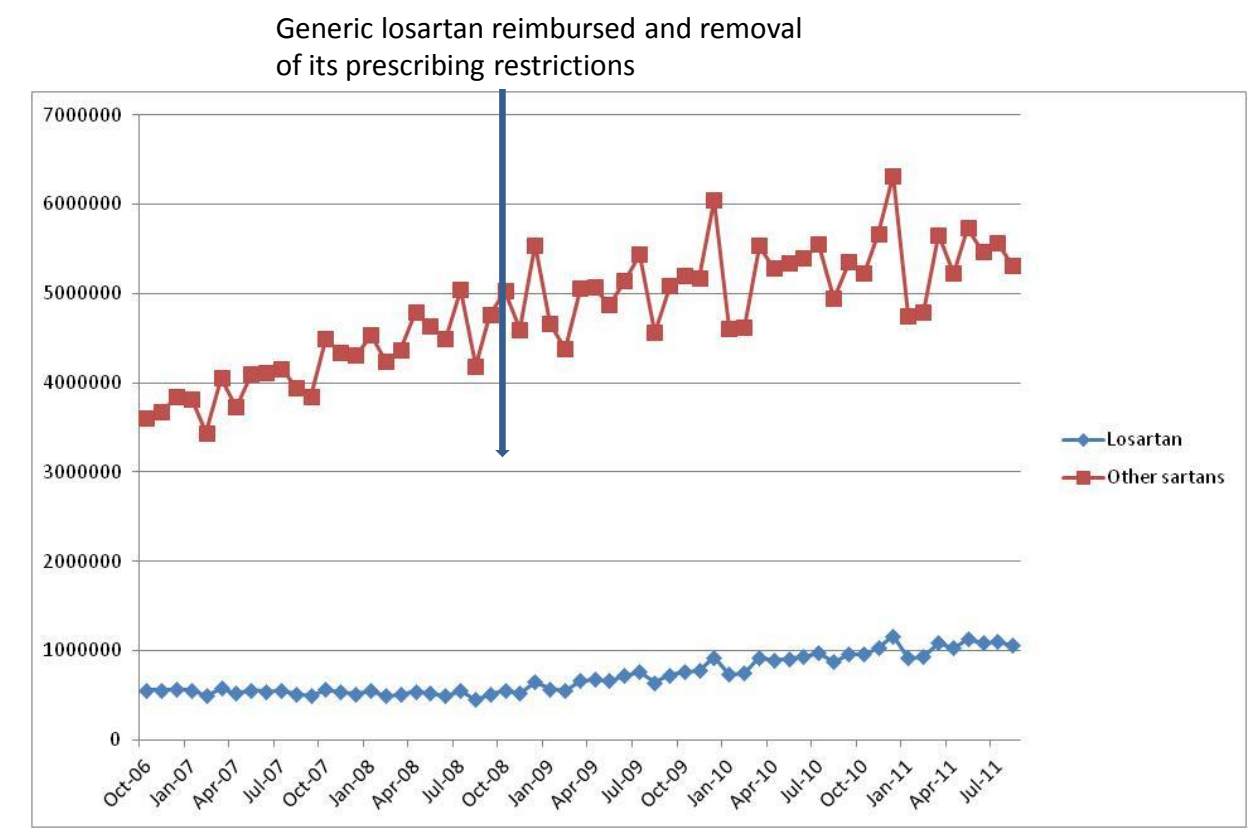

As a result of the lifting of prescribing restrictions, the utilisation of losartan as a $\%$ of all single ARB utilisation increased on a DDD basis from $12 \%$ on a moving annual total (MAT) basis 12 months before generic losartan was available and its prescribing restrictions removed, to $16 \%$ at the end of the study period on a MAT basis (Table 4). Generic losartan accounted for $46 \%$ of total losartan on a DDD basis in August 2011. The differences in utilisation patterns of the other single ARBs after the lifting of the prescribing restriction for losartan may have been influenced by the different marketing efforts of the various ARB manufacturers. However, this needs to be substantiated by formal market research before any definitive conclusions can be drawn.

Table 4 - ARB utilisation on a MAT basis using DDDs October 2006 to August 2011 in DDDs (1000)

\begin{tabular}{|l|c|c|c|c|c|c|}
\hline & $\begin{array}{c}\text { Total MAT DDD 12 months } \\
\text { before generic losartan }\end{array}$ & $\begin{array}{c}\text { Total MAT DDD at launch } \\
\text { of generic losartan }\end{array}$ & $\begin{array}{c}\text { Total MAT DDD 12 months } \\
\text { after generic losartan }\end{array}$ & $\begin{array}{c}\text { Total MAT DDD 24 months } \\
\text { after generic losartan }\end{array}$ & $\begin{array}{c}\text { Total MAT DDD 35 months } \\
\text { after generic losartan }\end{array}$ & $\begin{array}{c}\text { \% change MAT at 35 } \\
\text { months vs. MAT at launch }\end{array}$ \\
\hline Losartan & 6477.4 & 6236.98 & 7698.3 & 10394.1 & 12452.4 & 100 \\
\hline Eprosartan & 1587.7 & 1708.1 & 1647.4 & 1539.5 & 1416 \\
\hline Valsartan & 9227.1 & 10998.3 & 11834.6 & 12154.6 & 17 \\
\hline Candesartan & 28332.6 & 32502 & 35621.8 & 38330.5 & 12260.3 \\
\hline Telmisartan & 3718.5 & 4279.8 & 4611.2 & 4681.7 & 40071.4 \\
\hline Olmesartan & 3432.2 & 4667.5 & 5723.9 & 6328.1 & 4597.99 \\
\hline Total & 52775.5 & 60392.7 & 67137.2 & 73428.5 & 23 \\
\hline \% losartan vs. others & $\mathbf{1 2}$ & $\mathbf{1 0}$ & $\mathbf{1 1}$ & $\mathbf{1 4}$ & 7 \\
\hline
\end{tabular}

NB MAT = Moving Annual Total

The increased utilisation of candesartan, olmesartan and valsartan with their higher expenditure/ DDD than for losartan after the availability of generic losartan (Table 5) increased total ARB expenditure over the study period (Table 6).

Table 5 - Expenditure/ DDD for the various ARBs (Euros) MAT - October 2006 to August 2011 (MAT $\underline{\text { basis) }}$

\begin{tabular}{|c|c|c|c|c|c|c|}
\hline & $\begin{array}{c}\text { Expenditure/ DDD MAT } 12 \\
\text { months before generic } \\
\text { losartan }\end{array}$ & $\begin{array}{l}\text { Expenditure/ DDD MAT at } \\
\text { launch of generic losartan }\end{array}$ & $\begin{array}{c}\text { Expenditure/ DDD MAT } 12 \\
\text { months after generic losartan }\end{array}$ & $\begin{array}{l}\text { Expenditure/ DDD MAT } 24 \\
\text { months after generic losartan }\end{array}$ & $\begin{array}{c}\text { Expenditure/ DDD MAT } 35 \\
\text { months after generic losartan }\end{array}$ & $\begin{array}{c}\% \text { change MAT at } 35 \\
\text { months vs. MAT at launch }\end{array}$ \\
\hline Losartan & 0.91 & 0.91 & 0.60 & 0.26 & 0.20 & -78 \\
\hline Eprosartan & 0.80 & 0.78 & 0.78 & 0.78 & 0.78 & 0 \\
\hline Valsartan & 0.63 & 0.61 & 0.61 & 0.61 & 0.61 & -1 \\
\hline \begin{tabular}{|l|} 
Candersartan \\
\end{tabular} & 0.59 & 0.59 & 0.59 & 0.58 & 0.57 & -4 \\
\hline \begin{tabular}{|l|} 
Telmisartan \\
\end{tabular} & 0.58 & 0.57 & 0.57 & 0.57 & 0.57 & 0 \\
\hline Olmesartan & 0.71 & 0.72 & 0.72 & 0.73 & 0.73 & 1 \\
\hline Total & 0.65 & 0.64 & 0.61 & 0.55 & 0.53 & -17 \\
\hline
\end{tabular}

NB MAT = Moving Annual Total 
Having said this, the MAT increase in total single ARB expenditure for the 12 months to August 2011 (35 months after the availability of generic losartan) was only $7 \%$ higher than MAT expenditure at the launch of generic losartan (Table 6). This was despite a $28 \%$ increase in total single ARB utilisation during this period (Table 3 ), helped by a $78 \%$ reduction in MAT expenditure/ DDD for losartan during the course of the study period (Table 6 ).

Table 6 - Total expenditure (MAT) on individual ARBs (1000 Euros) October 2006 to August 2011 MAT basis

\begin{tabular}{|c|c|c|c|c|c|c|}
\hline & \begin{tabular}{|c|}
$\begin{array}{c}\text { Total MAT DDD } 12 \text { months } \\
\text { before generic losartan }\end{array}$ \\
\end{tabular} & \begin{tabular}{|c|}
$\begin{array}{c}\text { Total MAT DDD at launch } \\
\text { of generic losartan }\end{array}$ \\
\end{tabular} & $\begin{array}{c}\text { Total MAT DDD } 12 \text { months } \\
\text { after generic losartan }\end{array}$ & $\begin{array}{c}\text { Total MAT DDD } 24 \text { months } \\
\text { after generic losartan }\end{array}$ & $\begin{array}{c}\text { Total MAT DDD } 35 \text { months } \\
\text { after generic losartan }\end{array}$ & $\begin{array}{c}\text { \% change MAT at } 35 \\
\text { months vs. MAT at launch }\end{array}$ \\
\hline Losartan & 5869.5 & 5652.8 & 4597.9 & 2710.4 & 2494.5 & -56 \\
\hline Eprosartan & 1267.9 & 1335.97 & 1288.5 & 1204.1 & 1107.5 & -17 \\
\hline Valsartan & 5770.6 & 6739.2 & 7194.9 & 7379.3 & 7430.3 & 10 \\
\hline Candesartan & 16786.9 & 19129.4 & 20844.3 & 22074.4 & 22674.5 & 19 \\
\hline \begin{tabular}{|l|} 
Telmisartan \\
\end{tabular} & 2138.5 & 2454.8 & 2645.8 & 2675 & 2635.1 & 7 \\
\hline \begin{tabular}{|l|} 
Olmesartan \\
\end{tabular} & 2448.1 & 3369.9 & 4139.2 & 4606.1 & 4901.2 & 45 \\
\hline Total & 34282 & 38682 & 40711 & 40649 & 41243 & 7 \\
\hline
\end{tabular}

Expenditure/ DDD for generic losartan in August 2011 was Euro 0.154 (Figure 3), 83\% below the prepatent loss price. Expenditure/ 1000 inhabitants/ year was $€ 4950$ for the single ARBs at the end of the study period versus $€ 4689$ just before generic losartan was launched, equating to a $6 \%$ increase.

Figure 3 - Expenditure/ DDD in Euros for both originator and generic losartan from August 2008 (i.e. just before generic availability)

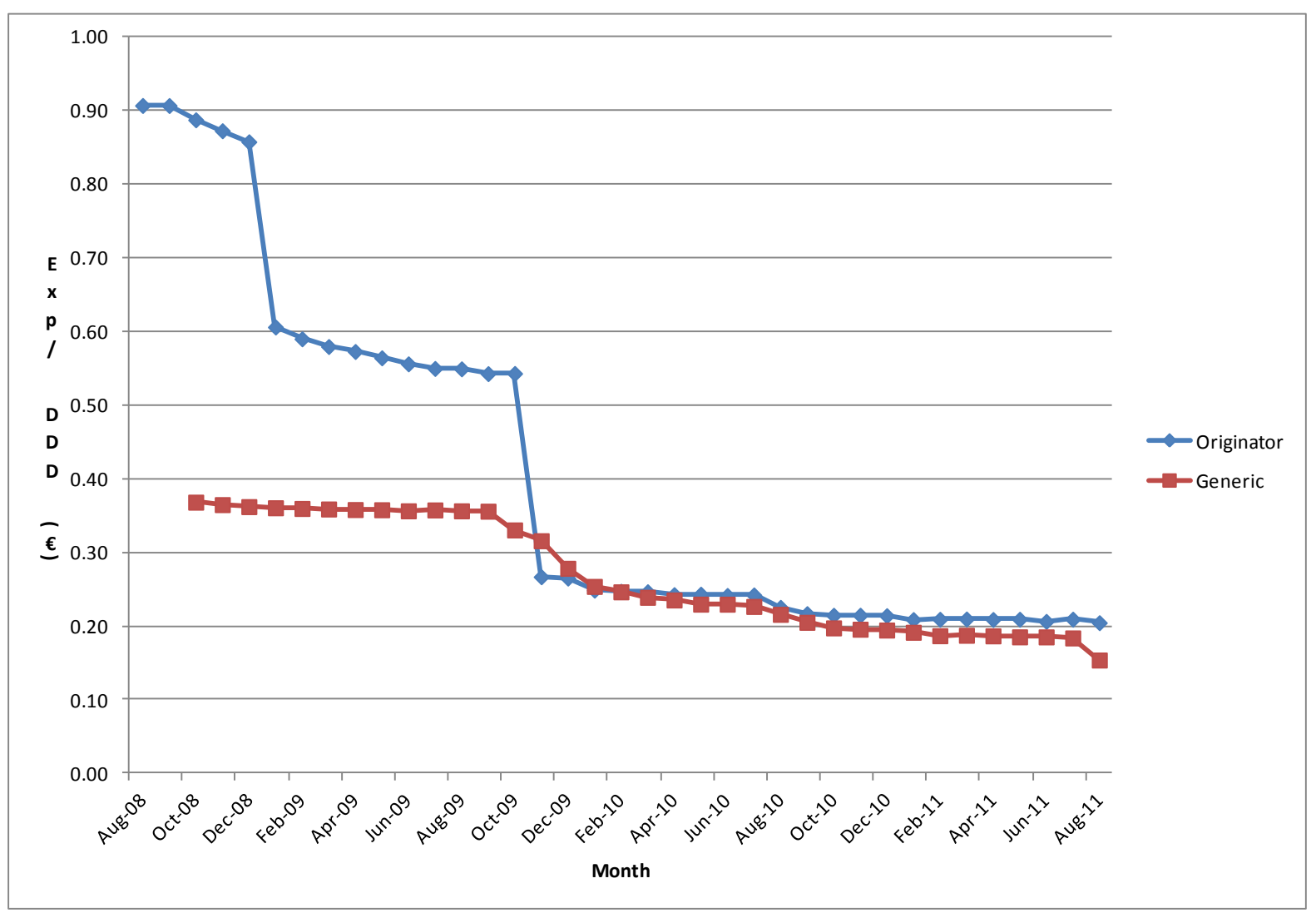

There was continued high utilisation of ARB fixed dose combination (FDC) products in Austria throughout the study period (Table 7). This remained relatively stable at $46 \%$ to $49 \%$ of total single ARBs plus ARBs combined with a diuretic in a FDC, and $49 \%$ to $50 \%$ when all FDCs are considered (Table 7). As previously stated, we believe this continued high utilisation of FDCs reflects existing prescribing habits, coupled with the difficulties with the supply of reimbursed generic diuretics in Austria. However, it is difficult to fully substantiate this without formal market research.

The utilisation of losartan FDC as a \% of total utilisation of all losartan fell though during the study period from $23 \%$ MAT 12 month before the availability of generic losartan to $18 \%$ MAT by 35 months 
after the availability of generic losartan. However, this was counter-balanced by the increased utilisation of all the other ARB FDCs after the availability of generic losartan, apart from valsartan FDCs (Table 7). These changes in utilisation patterns for the different FDCs may again have been influenced by the marketing efforts of the various manufacturers, with reduced activities by the manufacturer of originator losartan following the availability of generic losartan despite generic losartan FDCs not being available till March 2011. However, this again needs to be substantiated by formal market research before any definitive conclusions can be drawn.

Table 7 - Utilisation patterns of ARB combinations (1000 DDDs) October 2008 to August 2011 MAT $\underline{\text { basis }}$

\begin{tabular}{|c|c|c|c|c|c|c|}
\hline & \begin{tabular}{|c} 
Total MAT DDD 12 months \\
before generic losartan
\end{tabular} & $\begin{array}{c}\text { Total MAT DDD at launch } \\
\text { of generic losartan }\end{array}$ & $\begin{array}{l}\text { Total MAT DDD } 12 \text { months } \\
\text { after generic losartan }\end{array}$ & $\begin{array}{c}\text { Total MAT DDD } 24 \text { months } \\
\text { after generic losartan }\end{array}$ & $\begin{array}{l}\text { Total MAT DDD } 35 \text { months } \\
\text { after generic losartan }\end{array}$ & $\begin{array}{c}\% \text { change MAT at } 35 \\
\text { months vs. MAT at launch }\end{array}$ \\
\hline Losartan + diuretic & 11597.4 & 11955.6 & 11628.9 & 11114.3 & 11873.96 & -1 \\
\hline Eprosartan + diuretic & 128.2 & 657.4 & 985.6 & 1120.8 & 1127.4 & 71 \\
\hline \begin{tabular}{|l|} 
Valsartan + diuretic \\
\end{tabular} & 13023.6 & 14353.5 & 14950.8 & 14784.6 & 14062.5 & -2 \\
\hline \begin{tabular}{|l|} 
Candesartan + diuretic \\
\end{tabular} & 19519.1 & 21999.3 & 23549.7 & 24626.2 & 25600.2 & 16 \\
\hline Telmisartan + diuretic & 3789.9 & 4393.2 & 4887.9 & 5092.1 & 5092.2 & 16 \\
\hline Olmesartan + diuretic & 1756.6 & 3313.9 & 4630.4 & 5666.7 & 6541.6 & 97 \\
\hline Valsartan + amlodipine & 0.2 & 1571.7 & 3793 & 4966.3 & 5305.1 & 238 \\
\hline Olmesartan + amlodipine & 0 & 0 & 85.5 & 2471.6 & 4117.4 & $\mathrm{NA}$ \\
\hline Telmisartan + amlodipine & 0 & 0 & 0 & 0 & 13.4 & $\mathrm{NA}$ \\
\hline \begin{tabular}{|l|}
$\begin{array}{l}\text { valsartan, amlodipine + } \\
\text { hydrochlorothiazide }\end{array}$ \\
\end{tabular} & 0 & 0 & 0 & 369.7 & 2941.5 & NA \\
\hline \begin{tabular}{|l}
$\begin{array}{l}\text { olmesartan, amlodipine + } \\
\text { hydrochlorothiazide }\end{array}$ \\
\end{tabular} & 0 & 0 & 0 & 0 & 3.9 & NA \\
\hline $\begin{array}{l}\text { Total ARB + diuretic } \\
\text { combinations }\end{array}$ & 49815 & 56673 & 60633 & 62774 & 67243 & 19 \\
\hline $\begin{array}{l}\text { \% losartan combination vs. } \\
\text { All ARBs + diuretic }\end{array}$ & 23 & 21 & 19 & 18 & 18 & \\
\hline Total all ARB combinations & 49815 & 58245 & 64512 & 70212 & 76679 & 32 \\
\hline Total single ARBs & 52776 & 60392.8 & 67137.2 & 73428.5 & 77494 & \\
\hline \begin{tabular}{|l}
$\begin{array}{l}\text { Total single ARBs + diuretic } \\
\text { combinations }\end{array}$ \\
\end{tabular} & 102590 & 117066 & 127771 & 136203 & 144737 & \\
\hline Total all ARBs & 102591 & 118637 & 131649 & 143641 & 154173 & \\
\hline $\begin{array}{l}\% \text { combination ARB and } \\
\text { diuretics vs. all ARBs }\end{array}$ & 49 & 48 & 47 & 46 & 46 & \\
\hline $\begin{array}{l}\% \text { all ARB combinations vs. } \\
\text { all ARBs }\end{array}$ & 49 & 49 & 49 & 49 & 50 & \\
\hline
\end{tabular}

\section{Discussion and future implications}

The findings demonstrate that the lifting of prescribing restriction for losartan significantly enhanced its utilisation versus the other ARBs ( $P>0.001$ ), with the rate of growth in the utilisation of other ARBs declining ( $P>0.01$ ) (Tables 2 and 3 ). Having said this, the utilisation of the other ARBs in totality also increased following the availability of generic losartan (Figure 1), especially candesartan, olmesartan and valsartan (Table 4). However, the overall rate of their increase declined from the utilisation pattern seen before generic losartan (Figure 1). We accept that there are limitations with this finding as we have not been able to fully disassociate the influence of the changes in the prescribing restrictions for losartan with ongoing reforms to enhance the prescribing of generics. However as discussed earlier, these measures are aimed principally at increasing the prescribing of generics versus originators, with additional measures such as voluntary reference pricing and prescribing restrictions instigated to enhance prescribing efficiency of the class if needed. This is further confirmed by one of the main subjects among Quality Circles of ambulatory care physicians belonging to local Health Insurance Funds was to increase their use of generics [42]. Over a 3 year period, the prescribing of generics increased from $34 \%$ to $50 \%$ of products where a generic was available [42].

We believe the findings reflect that the majority of new patients are preferentially started on losartan, thereby reducing the need for extensive documentation among GPs before prescribing another ARB. In addition, we believe there has also been some switching of existing ARB patients to losartan when patients re-visit their GPs, as total ARB utilisation grew by $17.10 \mathrm{mn}$ DDDs from 12 months MAT before generic losartan to 35 months MAT after, with losartan accounting for an appreciable proportion of this increase at $6.215 \mathrm{mn}$ DDDs (Table 4). However, it is difficult to substantiate this without access to specific patient records and/ or specific market research among physicians. This was unlike the situation in Sweden when assessing the influence of the prescribing restrictions on the subsequent utilisation on ARBs first line [25], which is a recognised weakness of this study.

One potential reason for some switching, but not a high level with losartan only accounting for $16 \%$ of total single ARB utilisation on a MAT DDD basis 35 months after the lifting of its prescribing restrictions (Table 4), if our perceptions are correct, could be that ARB prescribing habits are ingrained after several years of prescribing restrictions for ARBs, and it is difficult to appreciably break 
these without specific activities. This mirrors the situation in Sweden where the imposition of prescribing restrictions for atorvastatin and rosuvastatin, along with the removal of lower strength atorvastatin and rosuvastatin 6 years after generic simvastatin, had limited influence apart from appreciably reducing the prescribing of lower strength atorvastatin and rosuvastatin [43].

Consequently to further influence future prescribing patterns, including both new and existing patients, particularly where products are not the most prescribed drug in a class, additional specific activities may be needed. These could include delisting of patented ARBs from the reimbursement list, which as the situation in Denmark, or active switching policies from patented ARBs to multiple sourced ARBs as seen in some UK Primary Care Trusts [Personal communication Andrew Martin]. Alternatively in the case of Austria, instigate formal prior approval for existing patented ARBs as more ARBs lose their patent, mirroring the situation with atorvastatin and rosuvastatin [20,21], with all ARBs being seen as essentially equal at optimal doses [31-33, 35-37,103]. This helped accelerate the utilisation of simvastatin over atorvastatin when introduced in Austria $[20,21]$, appreciably enhancing prescribing efficiency (Table 1). The potential restrictions for existing patented ARBs is now being actively considered to enhance prescribing efficiency, especially given the differences in expenditure/ DDD between generic and patented ARBs (Table 5).

As expected, increasing use of losartan at reduced expenditure/ DDD (Table 5, Figure 3), limited the increase in ARB expenditure by the end of the study period (Table 6), versus an appreciably higher increase in single ARB utilisation (Table 4).

Total expenditure/ DDD for both the originator and generic losartan fell in line with expectations (Figure 3) $[1,21,22]$. However, the mirroring of the reduction in total expenditure/ DDD for both the originator and generic losartan (Figure 3) may explain the still high utilisation of the originator losartan some 35 months after the availability of generic losartan, at $54 \%$ of total losartan utilisation. This is unlike the situation with generic omeprazole and generic simvastatin at $90 \%$ and $95 \%$ of total utilisation for the respective molecules in 2007 [21]. This is despite the ongoing initiatives to enhance the prescribing of generics versus originators once multiple sources are available described earlier $[1,21,22,42]$.

In conclusion, we believe the easing of prescribing restrictions for losartan significantly enhanced its utilisation versus other ARBs, although these continued to grow. We believe this is the first time that the easing of prescribing restrictions has been reported for one drug within a class certainly in Austria and possibly among Western European countries. Generally, studies have described the influence of instigating prescribing restrictions $[8,9,12,20-23,25,43-45]$. The lifting of the prescribing restrictions for losartan, coupled with ongoing measures to reduce the price of both originator and branded generic losartans once multiple sources became available, helped enhance ARB prescribing efficiency. As a result, providing guidance to other countries seeking further initiatives to enhance their ARB prescribing efficiency. However, additional reforms are needed to further improve ARB prescribing efficiency, especially when prescribing habits are ingrained. This mirrors the results from other studies where multiple demand side measures are needed to appreciably change utilisation patterns given the complexities of prescribing decisions $[4,8,9,12,15,41,46-48]$.

\section{Key issues}

- The restrictions limiting the prescribing of ARBs in ambulatory care to patients unable to tolerate the side-effects of ACEls helped reduce their utilisation in practice. These restrictions were lifted for losartan once generics were launched, but remained for all other patented ARBs

- The lifting of prescribing restrictions significantly enhanced the utilisation of losartan in ambulatory care, increased its utilisation as a \% of single ARBs from 12\% (MAT DDDs) just before generic availability to $16 \%$ at the end of the study period (35 months MAT). This included new patients prescribed losartan as their first ARB as well as patients switched from other ARBs

- Expenditure/ DDD for generic losartan was $83 \%$ below pre-patent loss prices by the end of the study period. Expenditure/ DDD for the originator also reduced, resulting in overall expenditure/ DDD for losartan reducing by $78 \%$ during the study period (MAT basis). As a result, total expenditure/ 1000 inhabitants/ year for single ARBs only increased by $7 \%$ versus pre-patent loss prices by the end of the study period compared with a $28 \%$ increase in utilisation

- There was appreciable utilisation of ARB fixed dose combinations (FDCs), mirroring previous findings, at $49 \%$ to $50 \%$ of total renin-angiotensin inhibitor drugs (DDD basis) 
- The results show that lifting prescribing restrictions for one drug in a class significantly enhances it utilisation. However, additional reforms will be needed to further improve prescribing efficiency when prescribing habits are ingrained, mirroring the findings in other countries.

\section{Financial \& competing interests disclosure}

The work was in part supported by a grant from the Karolinska Institutet.

$A B, T B$ and MS are employed by the HVB in Austria. The authors have no other relevant affiliations or financial involvement with any organization or entity with a financial interest in or financial conflict with the subject matter or materials discussed in the manuscript apart from those discussed.

No writing assistance was utilized in the production of this manuscript.

\section{References}

Papers of special note have been highlighted as:

* of interest

${ }^{* *}$ of considerable interest

1. Godman B, Buscics A, Burkhardt T et al. Insight into recent reforms and initiatives in Austria; implications for key stakeholders. Expert Rev Pharmacoeconomcis Outcomes Research 2008; 8:357371

*Gives a comprehensible description of ongoing reforms in Austria to enhance the quality and efficiency of ambulatory care prescribing for both new and existing drugs

2. Sermet C, Andrieu V, Godman B et al. Ongoing pharmaceutical reforms in France; implications for key stakeholder groups. Applied Health Economics and Health Policy 2010;8:7-24

3. Wettermark B, Godman B, Andersen K et al. Recent national and regional drug reforms in Sweden - implications for pharmaceutical companies in Europe. Pharmacoeconomics 2008; 26: 537-50

4. Godman B, Wettermark B, Hoffman $\mathrm{M}$ et al. Multifaceted national and regional drug reforms and initiatives in ambulatory care in Sweden; global relevance. Expert Rev Pharmacoeconomcis Outcomes Research 2009; 9:65-83

5. Cameron A, Ewan M, Ross-Degnan D et al. Medicine prices, availability and affordability in 36 developing and middle-income countries: a secondary abanlysis. Lancet 373: 240-49 (2009)

6. Garattini S, Bertele V, Godman B et al. Enhancing the rational use of new medicines across European healthcare systems - A Position Paper. Eur Jn Clinical Pharmacology 2008; 64:1137-8

7. Godman B, Shrank W, Wettermark B, Andersen M, Bishop I et al. Use of generics - a critical cost containment measure for all healthcare professionals in Europe? Pharmaceuticals 2010; 3:2470-94 doi 10.3390/ph/3082470 ISSN 1424-8247

8. Godman B, Shrank W, Andersen M et al. Comparing policies to enhance prescribing efficiency in Europe through increasing generic utilisation: changes seen and global implications. Expert Rev. Pharmacoeconomics Outcomes Res 2010; 10: 707-22

* Provides good examples of multiple demand side measures that can be introduced to appreciably enhance prescribing efficiency of existing drugs (PPIs and statins)

9. Godman B, Shrank W, Andersen M, et al. Policies to enhance prescribing efficiency in Europe: findings and future implications. Frontiers Pharmacol. 2011; 1 (141): 1-16 doi: 10.3389/fphar.2010.0014

10. Godman B, Haycox A, Schwabe U, Joppi R, Garattini S. Having your cake and eating it: Office of Fair Trading proposal for funding new drugs to benefit patients and innovative companies.

Pharmacoeconomics 2008; 26:91-8 
11. Godman B, Wettermark B, Bishop I, Burkhardt T, Fürst $\mathrm{J}$ et al. European payer initiatives to reduce prescribing costs through use of generics. GABI 2012; 1:22-27

12. Vončina L, Strizrep T, Godman B et al. Influence of demand side measures to enhance reninangiotensin prescribing efficiency in Europe; implications for the future. Expert Rev

Pharmacoeconomics and Outcomes Res 2011; 11: 469-79

* Provides good examples of multiple demand side measures that can be introduced to appreciably enhance prescribing efficiency of existing drugs (in this case renin-angiotensin inhibitor drugs)

13. Garuoliene K, Godman B, Gulbinovič J, Wettermark B, Haycox A. European countries with small populations can obtain low prices for drugs: Lithuania as a case history. Expert Rev.

Pharmacoeconomics Outcomes Res 2011; 11: 343-9

14. McGinn D, Godman B, Lonsdale J, Way R, Wettermark B, Haycox A. Initiatives to enhance the quality and efficiency of statin and PPI prescribing in the UK; impact and implications. Expert Rev Pharmacoeconomics and Outcomes Res 2010; 10: 73-85

15. Bennie M, Godman B, Bishop I, Campbell S. Multiple initiatives continue to enhance the prescribing efficiency for the proton pump inhibitors and statins in Scotland. Expert Review Pharmacoeconomics and Outcomes Research 2012; 12: 125-130

16. Dylst $P$, Vulton $A$, Simoens $S$. The impact of reference pricing systems in Europe: a literature reviews and case studies. Expert Rev Pharmacoeconomics and Outcomes Research 2011; 11:729737

17. Simoens S. A review of generic medicine pricing in Europe. GaBI 2012; 1:8-12

18. Godman B, Abuelkhair M, Vitry A, Abdu S et al. Payers endorse generics to enhance prescribing efficiency; impact and future implications, a case history approach. GABI 2012; 1(2): 21-35

19. Markovic-Pekovic V, Ranko Škrbić R, Godman B, Gustafsson LL. Ongoing initiatives in the Republic of Srpska to enhance prescribing efficiency; influence and future direction (Accepted for publication Expert Review of Pharmacoeconomics and Outcomes Research)

20. Godman B, Malmstrom RE, Bennie $M$ et al Prescribing restrictions - a necessary strategy among some European countries to enhance future prescribing efficiency? Reviews in Health Care 2012; 3: 5-16

${ }^{* *}$ Provides good examples of the influence of prescribing restrictions across Europe as well as potential pitfalls to avoid to ensure objectives are met

21. Godman B, Burkhardt T, Bucsics A et al. Impact of recent reforms in Austria on utilisation and expenditure of PPIs and lipid lowering drugs; implications for the future. Expert Rev Pharmacoeconomics Outcomes Research 9:475-84 (2009)

* Gives a good background of the influence of multiple measures on prescribing efficiency of PPIs and statins in Austria

22. Godman B, Buscics A, Burkhardt T, Schmitzer M, Wettermark B, Wieninger P. Initiatives to enhance renin-angiotensin prescribing efficiency in Austria; impact and implications for other countries. Expert Rev Pharmacoeconomics and Outcomes Research 10: 199-207 (2010)

* Gives a good background of the influence of prescribing restrictions on ARB utilisation in Austria

23. Godman B, Sakshaug S, Berg C, Wettermark B, Haycox A. Combination of prescribing restrictions and policies to engineer low prices to reduce reimbursement costs. Expert Rev. Pharmacoeconomics Outcomes Res. 2011; 11: 121-9

24. Coma A, Zara C, Godman B, Augusti A, Diogene E, Wettermark B, Haycox A. Policies to enhance the efficiency of prescribing in the Spanish Catalan Region: impact and future direction. Exp Review of Pharmacoeconomics and Outcomes Research 2009; 9: 569-81 
25. Wettermark B, Godman B, Neovius M, Hedberg N et al. Initial effects of a reimbursement restriction to improve the cost-effectiveness of antihypertensive treatment. Health Policy 2010; 94: 221-29

26. Gustafsson LL, Wettermark B, Godman B, Andersén-Karlsson E, Bergman U et al. The "Wise List"- A comprehensive concept to select, communicate and achieve adherence to recommendations of essential drugs in ambulatory care in Stockholm. Basic \& Clinical Pharmacology \& Toxicology $2011 ; 108: 224-233$

27. Godman B, Paterson K, Malmstrom R et al. Improving the managed entry of new medicines: sharing experiences across Europe (In Press Expert Review)

28. Fletcher A, Palmer A, Bulpitt C. Coughing with angiotensin converting enzyme inhibitors; how much of a problem? J Hypertens 12: S43-S47 (1994)

29. Frisk $\mathrm{P}$, Mellgren T-O, Hedberg $\mathrm{N}$ et al. Utilisation of angiotensin blockers in Sweden combining survey and register data to study adherence to prescribing guidelines. Eur Jn Clin Pharmacol 64: 1223-29 (2008)

30. Elliot H. Focus on the ONTARGET results. J Hypertens 27: S8-S10 (2009)

31. McDowell S, Coleman J, Ferner RE. Systematic review and meta-analysis of ethnic differences in risks of adverse reactions to drugs used in cardiovascular medicine BMJ 332:1177-81 (2006)

32. Moon J, Flett A, Godman B, Grosso A, Wierzbicki A. Getting better value from the NHS drug budget. BMJ 342: 30-32 (2011)

33. Heran BS, Wong MM, Heran IK, Wright JM. Blood pressure lowering efficacy of angiotensin receptor blockers for primary hypertension. Cochrane Database Syst Rev 2008(4):CD003822

** Main paper demonstrating similarity of ARBs for the management of hypertension

34. Nixon RM, Müller E, Lowy A, Falvey H. Valsartan vs. other angiotensin II receptor blockers in the treatment of hypertension: a meta-analytical approach. Int. J. Clin. Pract. 63:766-775 (2009)

35. Svanström H, Pasternak B, Hviid A. Association of treatment with losartan vs. candersartan and mortality among patients with heart failure. JAMA 307:1506-12 (2012)

36. Krum H. Optimising management of chronic heart failure. Lancet 374; 1808-9 (2009)

37. Konstam MA, Neaton JD, Dickstein $\mathrm{K}$ et al. Effects of high-dose versus low-dose losartan on clinical outcomes in patients with heart failure (HEAAL study): a randomised, double-blind trial. Lancet 374:1840-8 (2099)

38. Usher-Smith J, Ramsbottom T, Pearmain H, Kirby M. Evaluation of the clinical outcomes of switching patients from atorvastatin to simvastatin and losartan to candesartan in a primary care setting: 2 years on. Int J Clin Pract 62: 480-4 (2008)

39. Grimshaw J, Campbell M, Eccles M, Steen N. Experimental and quasi-experimental designs for evaluating guideline implementa-tion strategies. Family practice 17(Suppl. 1):S11-6 (2000)

40. Wagner AK, Soumerai SB, Zhang F, Ross-Degnan D. Segmented regression analysis of interrupted time series studies in medica-tion use research. Journal of Clinical Pharmacy and Therapeutics 27:299-309 (2002)

41. Vlahovic-Palcevski V, Gantumur M, Radosevic N et al. Coping with changes in Defined Daily Dose in longitudinal drug consumption databases. Pharm World Sci 32:125-9 (2010)

42. Spiegel W, Mlczoch-Czerny MT, Jens R, Dowrick C. Quality circles for pharmacotherapy to modify general practitioners' prescribing behaviour for generic drugs. J Eval Clin Pract 18:828-834 (2012) 
43. Pettersson $B$, Hoffmann M, Wändell P, Levin L-Å. Utilization and costs of lipid modifying therapies following health technology assessment for the new reimbursement scheme in Sweden. Health Policy doi:10.1016/j.healthpol.2011.10.010 (2011)

44. Sakshaug S, Furu K, Karlstad O et al. Switching statins in Norway after new reimbursement policy - a nationwide prescription study. Br J Clin Pharmacol 64, 476-81 (2007)

45. Martikainen J, Saastamoinen L, Korhonen $M$ et al. Impact of restricted reimbursement on the use of statins in Finland - A register-based study. Medical Care 48, 761-6 (2010)

46. Wettermark B et al. Soft regulations in pharmaceutical policymaking - an overview of current approaches and their consequences. Appl. Health Econ Health Policy 2009; 7: 137-47

* Good overview paper on potential ways to influence physician prescribing

47. Bero LA, Grilli R, Grimshaw JM et al. Closing the gap between research and practice: an overview of systematic reviews of interventions to promote the implementation of research findings. BMJ 317:465-8 (1998)

48. Barton S. Using clinical evidence. BMJ 322:503-4 (2001)

\section{Web based publications}

101. World Health Organisation (WHO) Guidelines for ATC classification and DDD assignment 2009. Oslo: WHO Collaborating Centre for Drug Statistics Methodology. www.whocc.no [Accessed 5 March 2012]

102. NHS. PCT prescribing report (November 2009). Prescribing of angiotensin-converting-enzyme (ACE) inhibitors and angiotensin-II receptor antagonists (AlIRAs) - Prescribing guidance and discussion points. Available via URL:

http://www.nhsbsa.nhs.uk/Documents/PPDPCTReports/pctreport_20092.pdf [Accessed 6 March 2012]

103. NICE updates its guidance on the management of hypertension. MeReC 10 October 2011. Available via URL: http://www.npc.nhs.uk/rapidreview/?p=4470 [Accessed 3 March 2012]

104. MeReC. Key Therapeutic Targets; Medicines Management Options for Local Implementation. July 2011. Available via URL:

http://www.npc.nhs.uk/qipp/resources/qipp_key_therapeutic_topics_july11_version3.1.v2.pdf [Accessed 3 March 2012]

105. MeReC. February 2012. Key Therapeutic Targets; Medicines Management Options for Local Implementation . Available via URL:

http://www.npc.nhs.uk/qipp/resources/Key_therapeutic_topics_Medicines_Management_for_local\%20 implementation_feb\%202012_final.pdf [Accessed 3 March 2012]

106. World Health Organization (WHO). Introduction to Drug Utilisation Research. WHO International Working Group for Drug Statistics Methodology, WHO Collaborating Centre for Drug Statistics Methodology, WHO Collaborating Centre for Drug Utilization Research and Clinical Pharmacological Services. ISBN 924156234 X (NLM classification: WB 330) Available via URL:

http://www.who.int/medicines/areas/quality_safety/safety_efficacy/Drug\%20utilization\%20research.pd $\mathrm{f}$ [Accessed 3 Marc 2012]

107. R Development Core Team (2012). R: A language and environment for statistical computing. $R$ Foundation for Statistical Computing, Vienna, Austria. ISBN 3-900051-07-0. Available via URL http://www.R-project.org/ [Accessed 8 April 2012] 